\title{
REFLECTION OF MUTHAHHARI MURTADHA THOUGHTS: Methodology, Epistemology and Thought Agenda
}

\author{
Zainal Abidin ${ }^{1}$ \\ ${ }^{1}$ Faculty Ushuluddin, Adab, and Dakwah, IAIN Palu, Palu, datokaramazen@yahoo.com
}

\begin{abstract}
Murtadha Mutahhari as a great Islamic figure and thinker has attracted the interest of many experts. This research is a research that also examines how the views of Murtadha Mutahhari in three major aspects, namely methodology, epistemology and agenda of thought. This research is a study of figures with a focus on thinking developed by Murtadha Mutahhari. The study of the thoughts of Mutahhari Mutahhari is carried out through a study of his works and the thoughts or views of experts regarding Mutahhari Murtadha. The results of this study indicate that Murtadha Mutahhari can elaborate rational-philosophical thinking with a strong religious understanding and produce an active style of thinking and in accordance with the current civilization.
\end{abstract}

Keywords: Murtadha Muthahhari, Islamic Scholar, Thought

\begin{abstract}
Abstrak. Murtadha Muthahhari sebagai seorang tokoh dan pemikir besar Islam telah menarik minat banyak ahli. Penelitian ini menjadi penelitian yang juga turut mengkaji bagaimana pandangan Murtadha Muthahhari dalam tiga aspek besar, yaitu metodologi, epistemologi dan agenda pemikirannya. Penelitian ini adalah studi tokoh dengan fokus pada pemikiran yang dikembangan oleh Murtadha Muthahhari. Kajian terhadap pemikiran Murtadha Muthahhari dilaksanakan melalui kajian terhadap karya-karyanya dan pemikiran atau pandangan para ahli mengenai Murtadha
\end{abstract}


Jurnal Hunafa: Studia Islamika, Volume 16, Number 2, p. 1- 150

E-ISSN: $2355-7710$

P-ISSN: $1411-125 \mathrm{X}$

Muthahhari. Hasil penelitian ini menunjukkan bahwa Murtadha Muthahhari dapat mengelaborasikan pemikiran rasional-filosofikal dengan pemahaman keagamaan yang kuat dan menghasilkan sebuah gaya pemikiran yang aktif dan sesuai dengan peradaban saat ini.

Kata Kunci: Murtadha Muthahhari, Pemikir Islam, Pemikiran

\section{INTRODUCTION}

When the Islamic world in the era of intellectual strife, Iran, as a Muslim country, still exists with fresh thoughts, especially in the field of philosophy. Iran is known for its 'irfani tradition which later gave birth to a number of figures such as Mulla Sadra, Muhammad al-Baqir, al-Thabathaba'i, Ali Shariati, Khomeini and others.

Among Iranian thinkers who are quite popular in this century are Murtadha Muthahari who is a direct student of al-Thabathaba'i and Khomeini. Motahhari is a prolific writer whose works have been translated into Indonesian. His writing discusses many things so it is not easy to know what his scientific specialization is. Muthahari's thought has been known in Indonesia since the 1980s. Even his philosophical thinking, has enriched the treasures of philosophical thought in Indonesia.

As a scholar, Muthahari's works are never separated from Islamic themes. However, what makes it different from the works of scholars in the country in general is the nuances of philosophy that colors all his writings. He is not only proficient in Islamic disciplines, but also has broad scientific insights including Western thoughts.

Mutahhari is not only a theorist who is only good at speaking and writing, but also a true activist and mujahid who also plays an important role as a fighter, founder and layer of the Islamic Republic of Iran. Motahhari, quoting the views of Haidar Bagir, was a scholar-thinker who knew well about what he 
Jurnal Hunafa: Studia Islamika, Volume 16, Number 2, p. 1- 150

E-ISSN: $2355-7710$

P-ISSN: $1411-125 \mathrm{X}$

thought and fought for. Behind dozens of his works were actually exposed by a big agenda, a big goal. More than that, the big agenda was to be achieved through a methodology that he had thought through carefully. ${ }^{1}$

This paper attempts to trace Motahhari's methods of thinking, his views on epistemology and further examines the agenda behind his works. And before that, his brief biography will be presented to understand the background and social settings surrounding the birth of the intellectual works of the character.

\section{SHORT BIOGRAPHY}

Murtadha Muthahari was born on February 2, $1919^{2}$ to a pious family in Fariman, Khurasan. His father was Hujjat Al-Islam, Muhammad Husein Murthahari, known as a pious and respected person, he was raised in the care and guidance of his father wisely until he was 12 years old. ${ }^{3}$

In $1356 \mathrm{AH}$ he left for Qum and studied under the guidance of two ayatollahs: Boroujerdi and Khomeini. While still a student, Muthahari had shown great interest in modern philosophy and science, he had studied the works of Aristotle, Will Durant, Sartre, Feud, Bertrand Russell, Einstein, Erich Fromm, Alexis Correll and other Western thinkers. His main teacher in the field of philosophy is Allamah Thabathabai, a great scholar who produces various philosophical works and composers of the interpretation of the Qur'an, al Mizan. ${ }^{4}$

${ }^{1}$ Haidar Bagir, “Membincang Metodologi Ayatullah Murtadha Muthahhari”, Research Report, (Universitas Gajah Mada, 2004), 1

${ }^{2}$ Muhsin Labib, Filosof Sebelum dan Sesudah Mulla Shadra, (Jakarta: Lentera, 2005) 278; Hamid Algar, "Hidup dan Karya Murtadha Muthahhari" in Murtadha Muthahhari, Filsafat Hikmah, Trans, (Bandung: Mizan, 2002), 23

${ }_{3}^{3}$ Jalaluddin Rahmat in Introduction of Murtadha Muthahhari, Perspektif Alqur'an tentang Manusia dan Agama, (Bandung: Mizan, 1990), 8

${ }^{4}$ Murtadha Muthahhari, Masyarakat dan Sejarah, (Bandung: Mizan, 1995), 4; Dewan Redaksi Ensiklopedi Islam, Ensiklopedi Islam, $3^{\text {rd }}$ Ed, (Jakarta: Ichtiar Baru Van Hoeve, 1994), 313 
Jurnal Hunafa: Studia Islamika, Volume 16, Number 2, p. 1- 150

E-ISSN: $2355-7710$

P-ISSN: $1411-125 \mathrm{X}$

In 1937 Motahhari settled in Qom. ${ }^{5}$ In this city, he became one of the most intelligent religious students. In this city, he was very appreciative of philosophical subjects. In depth, he learned this knowledge through 'Allamah Sayyid Muhammad Husein Thabathaba'i. This teacher introduced to Motahhari comprehensively about various forms of thought from Aristotle to Sartre. Thabathaba'i is the greatest Mufassir, Theosophist, and Philosopher in the 20th century M. Sayyid Husein Nasr who is a Thabathaba'i student, revealed that 'Allamah Thabathaba'i has advantages as a Shaykh in the field of shari'a and esoteric sciences. , at the same time a leading philosopher. ${ }^{6}$ In addition to studying philosophy with Thabathaba'i, Mutahhari also learned it from Ayatullah Al-Astiyani, and Shaykh Mahdi Al-Mazandarani. ${ }^{7}$

In 1946 he studied Kifayah al-Usul, a book of law under the guidance of Imam Khomeini. Through this book, he then began his commitment to study the philosophy of Marxism. His philosophical study also goes on by studying the book Al-Asfar Al-Arba'ah by Mulla Sadra. He began to study this book since 1949 under the care of Imam Khomeini. Mutahhari's excellent understanding of Sadra's philosophy helped to make him a Mulla Sadra theosophist. In 1950 Motahhari also studied the book of philosophy of Marxism by George Pulizer entitled Introduction to Philosophy, but only through its translation in Persian. In addition, together with Montezari and Behesyty, Mutahhari also studied various philosophical books by Ibn Sina to the Sabbaba'i. ${ }^{8}$

Mutahhari also studied fiqh and ushul fiqh through Ayatullah Burujerdi, ${ }^{9}$ Ayatullah Hujjat Kuhkamari, Ayatullah Sayyid Muhammad Damad, Ayatullah Sayyid Muhammad Reza Gulpayagani, and Ayatullah Hajj Sayyid Shadr

\footnotetext{
${ }^{5}$ Mulyadhi Kartanegara, Nalar Religius; Memahami Hakikat Tuhan, Alam, danManusia, (Jakarta: Erlangga, 2007), 91.

${ }^{6}$ Seyyed Hossein Nasr, "Pengantar", in Muhammad Husein Thabathaba'i, Hikmah Islam, Terj. Husein Anis Al-Habsy, (Bandung: Mizan, 1993), 7 156.

${ }^{7}$ Murtadha Muthahhari, Mutiara Wahyu, Trans. Syekh Ali al-Hamid, (Bogor: Cahaya, 2004),

${ }^{8}$ Mulyadhi Kartanegara, Nalar Religius; Memahami Hakikat Tuhan, Alam, danManusia., 91-92

${ }^{9}$ Muhsin Labib, Filosof Sebelum dan Sesudah Mulla Shadra, 279
} 
Jurnal Hunafa: Studia Islamika, Volume 16, Number 2, p. 1- 150

E-ISSN: $2355-7710$

P-ISSN: $1411-125 \mathrm{X}$

Al-Din Shadr. His success in studying this subject was marked by his passing on the exam to win the title of Ayatullah, the tittle of Mujtahid in Shia, in the presence of great scholars like Ayatullah Sad, Ayatullah Muhammad Muhaqqiq, and Ayatullah Muhammad Hujjat. ${ }^{10}$

In addition, Motahhari also studied Irfan with Ahyatullah Al-Uzhma Ruhullah Khomeini. Because Imam Khomeini was also a Marja-i Taqlid, Motahhari also studied the science of jurisprudence and usul fiqh from him, as well as actively participating in philosophical lectures held by the leader of the Islamic Revolution of Iran. ${ }^{11}$

Thabathabai explained about the figure of Mutahhari, that he had extraordinary intelligence and all my words were not in vain. He had the absorptive power I taught him, he was very pious, full of humanity and very moral, his presence in my lectures was so gripping that I felt like I danced with excitement. $^{12}$

At the age of 36 he has taught logic, philosophy and jurisprudence at the Theological Faculty of Tehran University, he also served as chairman of the Philosophy Department. The breadth of his knowledge is evident in the subjects he cares for: Figh, al-Usul, Kalam Science, al-Irfan (Tasauf), Logic and Philosophy. ${ }^{13}$

Mutahhari took part in a time that witnessed the swift flow of thought influences coming from the West. Besides the positive influences from the West, Motahhari felt the challenge of certain Western thoughts on religion. Among the challenges that felt very pressing was Marxism. Since the 60s, Iran has indeed been hit by many of these influences. The effect is getting stronger and stronger. This can be seen, among others, in the emergence and strengthening

\footnotetext{
${ }^{10}$ Abdullah Beik, "Murtadha Muthahhari; Muslim dalam Aqidah, Syari'ah dan Akhlaq", AlIsyraq, 1996

${ }^{11}$ Murtadha Muthahhari, Mutiara Wahyu, 155-156

${ }^{12}$ Hernowo,"Tamasya Intelektual Seorang Ulama", Al- Hikmah: JurnalStudi-Studi Islam, No. 1, (1990), 109

${ }^{13}$ Murtadha Muthahhari, Masyarakat dan Sejarah, 4
} 
Jurnal Hunafa: Studia Islamika, Volume 16, Number 2, p. 1- 150

E-ISSN: $2355-7710$

P-ISSN: $1411-125 \mathrm{X}$

of left-wing parties and groups. He stated: "At present, among certain Muslim writers, the tendency towards Marxism and the view that Islam contains Marxist ideas, gained wide acceptance and was seen as a sign of the breadth of the mind and modes which again ..." At the same time, Motahhari also felt the influence of other Western ideologies that had a firm grip on Muslim countries, including Iran. That is materialism. He was even a pillar of various understandings that emerged in modern Western civilization ${ }^{14}$

During Motahhari's time, the government of the state was controlled by the Pahlavi regime. Seeing the continuing evil of the regime, together with Imam Khomeini and the community, he also fought against the power of the government that was not small. Because of his opposition to this government, he and Imam Khomeini were imprisoned by the government in 1963. After Imam Khomeini was exiled to Turkey, Motahhari was released. But by the order of Imam Khomeini, Motahhari led the struggle of the Iranian Revolution which was also supported by Iranian society and ulemas. Furthermore, in 1971, he was responsible for determining ideological political plans in the Al-Jawad mosque. To take various policies, he always asked Imam Khomeini for advice, especially in important political matters. ${ }^{15}$

His brilliant brain and broad knowledge can provide a comfortable life for him. But he chose the storm over peace, he wrote a lot and was active in preaching. His writings are still read by people without losing his actuality, he is one of the architects of the Iranian Revolution. Motahhari heads the group of Mujahideen clerics and becomes a member of the Revolutionary Council when the Revolution erupts. ${ }^{16}$

Three months before the spectacular victory of the Revolution, he breathed his last (May 2, 1979) due to the terrorist bullets furqan (extremist left

\footnotetext{
${ }^{14}$ Haidar Bagir, "Membincang...”,op. cit., h. 4

${ }^{15}$ Sastan Rastan, "Syahid Murtadha Muthahhari; Pembangkit Kebangunan Intelektual Islam”, Yaum Al-Quds, (No. 9, Ramadhan 1403 H.), h. 9; Jalaluddin Rahmat in Introduction Murtadha Muthahhari, Perspektif Alqur'an tentang Manusia dan Agama, 9

${ }^{16}$ Dewan Redaksi Ensiklopedi Islam, Ensiklopedi Islam, ${ }^{\text {3rd }}$ Ed, 314
} 
Jurnal Hunafa: Studia Islamika, Volume 16, Number 2, p. 1- 150

E-ISSN: $2355-7710$

P-ISSN: $1411-125 \mathrm{X}$

group). The event shocked the Iranian people and hurt the freedom fighters, because Motahhari for them was not only a brilliant thinker or as the voice of the oppressed people, but also as persistent freedom fighters, especially in freedom of thought. ${ }^{17}$

May $3^{\text {rd }}, 1979$ was made a national day of joining and I, Khomeini said, would sit in mourning on Thursday and Friday at Madrasa Fiziyah. ${ }^{18}$

In his works can be found an interdisciplinary methodology born from the world of traditional scholars. ${ }^{19}$ Or in other words he has made many attempts to develop a multidisciplinary basis for an Islamic world view. Nearly sixties more of his writings led to the formulation of the Islamic worldview. ${ }^{20}$

The strength of his analysis and his in-depth mastery of various fields of science, made his studies of the problems faced by Muslims in the modern age alluring all levels, especially Muslim intellectuals who were thirsty for Islamic information about the main themes facing modern humans. So it is not surprising, his works are translated into many languages; English, Arabic, Irdu and Indonesian.

His works which have been translated into Indonesian: Muqaddinah Islamic World View, (incomplete) consisting of seven languages about humans, the meaning and purpose of life, its relationship with Allah and the universe, its role in society and history and so on. Women's Rights in Islam, Hijab Issues, Qur'anic Perspectives on Humans and Religion, the Mujtahid, Monotheistic World View, Society and History, Reaching the Future, Whole Humans: Critical Studies of Various Philosophical Views, Philosophical Movements Islam, Islam and the Challenges of the Age, Divine Justice, Stepping on the Spiritual Path, Islamic Leadership and a number of writings in the article.

\footnotetext{
${ }^{17}$ Jalaluddin Rahmat in Introduction Murtadha Muthahhari, Perspektif Alqur'an tentang Manusia dan Agama, Pengantar, 10

${ }^{18}$ Ibid., 7

${ }^{19}$ Traditional refers to the understanding of knowledge dicipline with main point in the combination of Fighi and Tafsir Alqur'an with Philosophy, Teosophy, and tasawuf.

${ }^{20}$ Hernowo, "Tamasya Intelektual Seorang Ulama", 108
} 


\section{METHODOLOGY OF MUTHAHHARI THOUGHTS}

Every great thinker has a certain method of thinking in each form of thought. The method of thinking usually colors the entire results of his thinking, and even is the 'single root' of all the approaches and ideas that he puts forward. ${ }^{21}$ Likewise, Mutahhari certainly has a method of thinking that is the common thread of all his work and even his political activities. However, it is not easy to map the methodology of Motahhari's thought, as it has been stated, his work is so numerous and in various fields and themes of study. ${ }^{22}$

It is commonly known that in the twentieth century, Hawzah Qom was colored by several schools of thought, including; first, Rationalism-Textualism, one of the schools in the Qom school which makes ratios the basis and then provides justification with religious texts. Second, Textualism-Rationalism, namely the flow that makes religious texts as postulates and makes the ratio as a justification tool. Third Textualism-Rationalism-Theosophism, namely the flow that combines ratios, religious texts and irfan. Fourth, theosophy, namely the flow that prioritizes 'irfan or emotions in understanding reality.Fifth, RationalismModernism, which is a flow that uses ratio and modern knowledge. Sixth, NeoParipatetism, which is a flow that does not fully support IbnSina's view, but methodologically resembles that of IbnSina who uses a lot of deduction in his analysis. ${ }^{23}$

Based on this category, it seems that Motahhari was one of Iran's great thinkers who belonged to the group Rationalism-Textualism, ${ }^{24}$ a school that made

\footnotetext{
${ }^{21}$ Syahrin Harahap, Metodologi Studi Tokoh Pemikiran Islam, (Jakarta: Istiqamah Mulya Press, 2006), 38

${ }^{22}$ Haidar Bagir, Murtadha Muthahhari; Sang Mujahid, Sang Mujtahid, (Bandung: YayasanMuthahhari, 1988), 83-86.

${ }^{23}$ Muhsin Labib, "Hawzah Ilmiyah Qom; Ladang Peternakan Filosof Muslim Benua Lain", Jurnal Kajian Ilmu-ilmu Islam Al-Huda, Vol. III. No.9. 2003, 162

${ }^{24}$ Ibid.
} 
Jurnal Hunafa: Studia Islamika, Volume 16, Number 2, p. 1- 150

E-ISSN: $2355-7710$

P-ISSN: $1411-125 \mathrm{X}$

ratios (mind) as the basis of thought and used religious texts as justifications for the foundation which had been constructed by reason. This method of thinking is indeed very clear in Motahhari's various works. He always began the discussion by using rational arguments and in the end, to support his thinking, he used religious texts.

Mutahhari is very appreciative of reason. As revealed by Muhammad Ja'far, philosophy as a discipline that stands on the power of reasoning, has a quite special place in all lines of Mutahhari's conception of thought. Even so, it does not mean that the figure of Mutahhari put aside religious texts and the dimensions of spirituality and only relies on mere ratios. He also condemned thinkers who only fully rely on mind or ratio, without considering the texts of religion and spirituality. ${ }^{25}$ Apparently, Motahhari wanted to show that reason does not contradict religious texts, but has close links, even support one another.

According to Haidar Bagir, basically Motahhari's methodology is rationalphilosophical. This, according to him, is evident in his works, Motahhari used to discuss every issue first and rationally and philosophically, then later verify it on the basis of Islam: the Qur'an and Hadith. And not vice versa. That is why, Mutahhari in Iran, together with Ayatullah Muhammad Taqi Ja'fari, is known as part of the "Kalami sect" group. ${ }^{26}$

The term rational-philosophy used by Haidar Bagir in describing the methodology of Motahhari's thought, seems to have the same meaning as the term Rationalism-Textualism used by Muhammad Ja'far. In essence, the two agreed that Motahhari always used philosophical rational arguments in his works, and then put forward the texts as supporters. Such methods are commonly used by theologians.

\footnotetext{
${ }^{25}$ Muhammad Ja'far, "Pandangan Muthahhari Tentang Agama, Sejarah, Al Quran dan Muhammad”, Jurnal Kajian Ilmu-Ilmu Islam Al-Huda, Vol. III, No.11, 2005, 96.

${ }^{26}$ Haidar Bagir, "Membincang Metodologi Ayatullah Murtadha Muthahhari”
} 


\section{A MAHAHHARI VIEW OF EPISTEMOLOGY}

The word epistemology comes from Greek, which is from the word 'episteme', which means 'science'. This epistemology is known as the branch of philosophy that studies everything related to knowledge, such as basic characteristics, properties, types, objects, structures, origin, methods, and validity of science. ${ }^{27}$ The following presentation will review Motahhari's thoughts about the significance of epistemological studies, the possibility of epistemology, the classification of knowledge, sources and tools of epistemology, and the characteristics of sensory knowledge and ratios.

The importance of epistemology

Mutahhari has a serious concern with epistemology. When he was still alive, Motahhari often held various lectures which were attended not only by young Iranians, but also students. In quantity, their number can reach thousands of people. In $1977 \mathrm{AD}$, he gave lectures on epistemology in Tehran. These lectures have produced a book called "Mas'ale-ye Syenokh" (epistemological problems). Feeling that this was not enough, Motahhari had written a book about the same discussion entitled "Syenokh Dar Quran" (Epistemology in the Qur'an). All of that is still complemented by a philosophical discussion of this epistemological problem in the sharia he wrote of the philosophical book of the great philosophers of Iran in the last centuries, MullaHadiSabzawari, SyarhManzhumah. In this last book, Mutahhari states: "Even so it determines epistemology and, although the discussion of epistemology has been pioneered since more than two centuries ago, including also in Islamic philosophy, most of the issues concerning this issue are dealt with separately in various discussions

${ }^{27}$ Bagobert D. Runes, Dictionary of Philosophy, (Tottawa New Jersey: Adam's \& Co, 1971), 94; Harun Nasution, Filsafat Agama, (Jakarta: Bulan Bintang, 1973), 10; Loren Bagus, Kamus Populer Filsafat, (Jakarta: Gramedia, 1996), 212 
Jurnal Hunafa: Studia Islamika, Volume 16, Number 2, p. 1- 150

E-ISSN: $2355-7710$

P-ISSN: $1411-125 \mathrm{X}$

regarding science, knowledge, understanding, ratios, logic, and various problems related to the form of thought and in the discussion of the soul (nafs). In the past, more or less people have understood the importance of epistemology, but in this day and age everything related to the world view embraces this problem. ${ }^{28}$ These facts show that Motahhari is very concerned about the problem of epistemology.

Although the books by Mutahhari each discuss epistemological issues, the approaches used differ. In "Mas'ale-ye Syenokh", besides using the Quranic approach, Motahhari also uses a psychological approach. Whereas in "Syenokh Dar Quran", he instead discusses epistemology with the Quranic approach alone. And in the syarahannya book "SyarhManzhumah", and the book Usus-e FalsafahwaRawisy-e Rialism, Mutahhari only discusses the epistemological theme using a philosophical approach. ${ }^{29}$

Why did Motahhari pay so much attention to the problem of epistemology? It seems that this is due to several reasons, which will be discussed further in the next sub section on the agenda of Motahhari's thought. Previously, his brief view will be presented on: whether or not the study of epistemology, criticism of the dichotomy of knowledge, sources of knowledge, and epistemological tools.

The Possibility of Epistemological Studies

For a long time, philosophers had discussed whether epistemology was possible? Can someone know and understand the nature of nature and humans? Can someone achieve true truth? Or is it possible for humans to gain knowledge? These are the most fundamental themes in the study of epistemology.

${ }^{28}$ Haidar Bagir, "Membincang Metodologi Ayatullah Murtadha Muthahhari”, h.5;

${ }_{29}$ Murtadha Muthahhari, Mengenal Epistemologi: Sebuah Pembuktian Terhadap Rapuhnya Pemikiran Asing dan Kokohnya Pemikiran Islam,Trans, (Jakarta: Lentera, 2001), 11-15 
Jurnal Hunafa: Studia Islamika, Volume 16, Number 2, p. 1- 150

E-ISSN: $2355-7710$

P-ISSN: $1411-125 \mathrm{X}$

Motahhari argues that epistemology is possible in aqli. That human are able to gain knowledge, and this can be proven aqliyah. Mutahhari flatly rejected the view of Pyrho, a Greek philosopher that man was unable to know and understand. Pyrho states that the expression "I don't know" is a definite rule and fate of humans. This Greek philosopher also stated that there are two instruments in humans to know something, namely the senses and minds. These two instruments, according to him, can make mistakes, although they can also do a little right. On this basis, Pyrho states that something that is potentially wrong cannot be used as a backrest. ${ }^{30}$

Motahhari gave a simple criticism. According to him, Pyrho has found the essence. Because this Greek philosopher and his supporters, have discovered a mistake by means of a belief. They have the belief that they have discovered various senses and ratios. According to Motahhari, this statement is knowledge. In other words, if someone states that the ratio and the senses have a mistake, then that person believes that the ratio and the senses make a mistake, then the statement is the same as "I know that the ratio and the senses have made a mistake". His knowledge of the errors of ratio and senses is knowledge, and this is true. When humans have not reached the essence, then the human will not know the error in front of him. ${ }^{31}$ This is clear evidence that epistemology is possible literally.

Furthermore, Mutahhari also proved the possibility of epistemology with the Quranic approach. He is of the view that the Qur'an recognizes the possibility of gaining knowledge. Strictly the Qur'an invites humans to knowledge. In the Qur'an there are commands to pay attention, see, and contemplate everything. For example, commands pay attention to everything in heaven and earth. ${ }^{32}$

${ }^{30}$ Ibid., 30

${ }^{31}$ Ibid.

${ }^{32}$ Ibid., 42 
Jurnal Hunafa: Studia Islamika, Volume 16, Number 2, p. 1- 150

E-ISSN: $2355-7710$

P-ISSN: $1411-125 \mathrm{X}$

Even according to Mutahhari the Qur'an has emphasized the possibility of humans obtaining the truth. The Qur'an invites people to know Allah, the world, himself, and history. According to him, the story of Adam above, which is actually a story about humans, explains that Adam was considered by Allah SWT to be precise enough to know all the names of Allah SWT and the realities of the universe. Even in certain cases, human knowledge can understand some of Allah SWT's knowledge points. Motahhari quoted surah Al-Baqarah verse 255 to support this view. ${ }^{33}$

\section{Criticism of the Science Dichotomy}

Mutahhari is of the view that "science" in the Islamic view is all knowledge that brings problems to society. Therefore, Islam commands to seek knowledge in the sense of all knowledge that can help the fulfillment of individual, community and sacred goals of Islam. And vice versa, forbidding any kind of knowledge that is not useful or brings bad influence, both for individuals, society and the sacred goals of Islam. ${ }^{34}$

Therefore, Motahhari did not agree with the dichotomy of science into theology and non-religion. ${ }^{35}$ The reason for his rejection is: ${ }^{36}$ first, if the meaning of 'science in Islam only means 'religious sciences', then in essence Islam only encourages Muslims to themselves (Islam). Thus, it means that Islam does not say anything about science, in the sense, knowledge of the nature of creation. Also means, Islam remains in the first form and condition. Logically, although a teaching is hostile to science, and opposes the level of progress in the thinking and knowledge of Islamic societies, it certainly will not oppose itself. In short, if

\footnotetext{
${ }^{33}$ Murtadha Muthahhari, Manusia dan Alam Semesta: Konsepsi Islam tentangJagat Raya, Trans, (Jakarta: Lentera, 2002), 183.

${ }^{34}$ Murtadha Muthahhari, Ceramah-Ceramah Seputar Persoalan Penting Agama dan Kehidupan, $2^{\text {nd }}$ Ed, Trans, (Jakarta: Lentera, 2000), 273, 269.

${ }^{35}$ Murtadha Muthahhari, Ceramah-Ceramah Seputar Persoalan Penting Agama dan Kehidupan, $1^{\text {st }}$ Ed, Trans, (Jakarta: Lentera, 1999), 177

${ }^{36}$ Murtadha Muthahhari, "Ceramah-Ceramah Seputar Persoalan Penting Agama dan Kehidupan, $2^{\text {nd }} \mathrm{Ed}, 267-272$
} 
Jurnal Hunafa: Studia Islamika, Volume 16, Number 2, p. 1- 150

E-ISSN: $2355-7710$

P-ISSN: $1411-125 \mathrm{X}$

the meaning of 'science' ordered by Islam is only 'religious sciences', it can be said that the Islamic agreement on science is nil so that the Islamic view of science is negative.

Second. The meaning of the hadith, that "wisdom is the property of a lost believer, then take him even though you have to take it from the polytheists" and the hadith "Seek knowledge even to China", is general. The meaning of the word 'science' in the hadith is also general, not specific to 'religious sciences' alone. Because there really is no connection between China and 'religious sciences', just as there is no connection between the Mushrikans and 'religious sciences'.

Third, the logic of the Qur'an al-Karim about science does not take the form of something that is special. The Qur'an calls on Muslims to think about and study various problems, including all the phenomena of the universe. An example is like the word of Allah SWT in surah Al-Baqarah verse 164; "Indeed, in the creation of the heavens and the earth, the alternation of night and day, the ark that sailed in the sea brought what is useful to humans, and what Allah sent down from the sky in the form of water, then with that water he revived the earth after his death (dry) and he spreads on earth all kinds of animals, and the controlled range of wind and clouds between heaven and earth; indeed (there are) signs (oneness and greatness of Allah) for those who think". According to him the verse shows that the Qur'an explicitly calls on Muslims to study the phenomena of the universe. Of course, the call to study the universe will lead to all the knowledge that is considered as 'nonreligious science'.

Fourth, that Islamic teachings begin with monotheism. While monotheism is rational. Muslims are also forbidden from being religious. Muslims must have rational arguments about the teachings of Islam, before they accept the Islamic belief. Thus, Muslims are allowed to study monotheism. In turn, to study this monotheism, inevitably, Muslims must utilize their potential to study nature. Because in the perspective of the Qur'an al-Karim, one method of finding true monotheism is to pay attention to the entire sheet of nature's creation. 
Jurnal Hunafa: Studia Islamika, Volume 16, Number 2, p. 1- 150

E-ISSN: $2355-7710$

P-ISSN: $1411-125 \mathrm{X}$

Meanwhile, to unlock all the secrets of creation, Muslims must have knowledge such as biology, zoology, navigation, physics, chemistry, astronomy, and others. Without it, Muslims will not be able to study the universe properly, and in its effect, Muslims will lose one method of getting true monotheism.

Sources of Knowledge

In general, Mutahhari divides epistemological sources into two types, namely external and internal sources. This outer source is only one namely nature. While there are two sources in the ratio and heart. ${ }^{37}$

Nature as one source of epistemology includes material nature, the realm of space and time, the realm of movement, or the realm in which humans live. For humans to gain knowledge from nature, they must actualize all of their senses. ${ }^{38}$ The validity of nature as one of the sources of epistemology in Islam is widely stated by the Qur'an. The Qur'an often calls on people to contemplate material nature such as heaven and earth. ${ }^{39}$

The next source of epistemology, for Mutahhari, is the source from within man, that is ratio and heart. For him, the ratio is believed to give birth to science. This source will only produce knowledge if humans use syllogism and demonstration tools. If this is not done, then human beings will not be able to gain knowledge. The ratio is undoubtedly said to be one source of epistemology that gets the legitimacy of the Qur'an. He stated that the Qur'an itself believes in the reliability of reason as a source of knowledge and the truths obtained by reason. In fact, it is not uncommon for the Qur'an to use arguments that are based on reason. To support this view, Motahhari quoted a number of verses

\footnotetext{
${ }^{37}$ Muthahhari, Mengenal Epistemologi: Sebuah Pembuktian Terhadap Rapuhnya Pemikiran Asing dan Kokohnya Pemikiran Islam, 86.

${ }^{38}$ Ibid., 81-82

${ }^{39}$ Muthahhari, Manusia dan Alam Semesta: Konsepsi Islam Tentang Jagat Raya, 183.
} 
Jurnal Hunafa: Studia Islamika, Volume 16, Number 2, p. 1- 150

E-ISSN: $2355-7710$

P-ISSN: $1411-125 \mathrm{X}$

from the Qur'an al-Karim, such as the surah Al-Anbiya': 22 and surah AlMukminun: $91{ }^{40}$

The third source of epistemology according to Motahhari is the heart. According to him, through this source, humans will be able to get inspiration and revelation from Allah SWT. A Muslim's belief that the heart as one source of epistemology is based on that Muslim's belief in the existence of a realm behind this physical realm, known as the metaphysical realm. This is because inspiration as a form of knowledge from the source of the heart comes from non-physical nature. In order for a person to gain knowledge from the source of the heart, humans must use the tazkiyatun nafs (purification of the heart) method. He wrote: "Every human being can receive inspiration in accordance with his sincere dedication and efforts to maintain purity and spiritual activities in this center (heart). The revelation of the prophets is the highest form of knowledge like this". ${ }^{41}$

Making the heart a source of knowledge is one of the differences in Mutahhari's views from the secular Western philosophers. And in this aspect it seems clear that Motahhari rests on Islamic teachings.

There is still another epistemological source called Mutahhari, although it is not explained whether this source is categorized as an internal source or an external source. The source in question is history. According to him, history has an important meaning as one of the sources of epistemology that is validated by the Qur'an al-Karim. In other words, the Qur'an proves the significance of history as a source of epistemology. So, besides nature, ratio, heart, the Qur'an expressly recognizes history as a source of epistemology. This can be seen how the Qur'an commands humans to make history as study material. Motahhari quoted surah al-An'am: 11 as a supporter of his view. "Say: "Walk on the earth, then pay attention to how the end of the deniers." For this character, this verse clearly

\footnotetext{
${ }^{40}$ Muthahhari, Mengenal Epistemologi: Sebuah Pembuktian Terhadap Rapuhnya Pemikiran Asing dan Kokohnya Pemikiran Islam, 86-87.

${ }^{41}$ Muthahhari, Manusia dan Alam Semesta: Konsepsi Islam Tentang Jagat Raya, 184.
} 
Jurnal Hunafa: Studia Islamika, Volume 16, Number 2, p. 1- 150

E-ISSN: $2355-7710$

P-ISSN: $1411-125 \mathrm{X}$

calls for people to pay attention to various historical relics. Humans must pay attention to changes in history contained in human life and social. By paying attention to history, people will find various historical changes that occur in various societies. After that, humans will find that history actually contains a variety of information and knowledge from the beginning of the world to the end. ${ }^{42}$

Means of Epistemology

According to Mutahhari, humans must function their epistemological means to be able to obtain knowledge from the epistemological sources that have been mentioned. And because the epistemological sources vary, the means of acquisition also varies according to the source.

At least, according to him, there are four types of means to obtain knowledge. These four types of facilities are owned by every human being and are created as a means of gaining knowledge. The four means referred to are the senses (tajribah), logical argumentation (burhan), purification of the heart (tazkiyatun nafs), ${ }^{43}$ and study of other people's scientific works. ${ }^{44}$

To support his view, Motahhari refers to a number of verses in the Qur'an, among others, surah Al-Nahl: 78 "And Allah brought you out of your mother's stomach in the condition of not knowing anything, and he gave you hearing, vision and heart, so that you will be grateful". According to him, this verse clearly shows that the sensory and logical argumentation as a means of epistemology. The other three senses are indeed not mentioned in this verse, because for Mutahhari these ears and eyes have a greater influence in epistemology when compared to the other three senses. Ears and eyes are known to have a greater ability to

\footnotetext{
${ }^{42}$ Muthahhari, Mengenal Epistemologi: Sebuah Pembuktian Terhadap Rapuhnya Pemikiran Asing dan Kokohnya Pemikiran Islam, 103-106

${ }^{43}$ Ibid., 87

${ }^{44}$ Muthahhari, Manusia dan Alam Semesta: Konsepsi Islam Tentang Jagat Raya, 184.
} 
Jurnal Hunafa: Studia Islamika, Volume 16, Number 2, p. 1- 150

E-ISSN: $2355-7710$

P-ISSN: $1411-125 \mathrm{X}$

produce knowledge. While the sense of touch, taste, and smell although they also have the ability to produce knowledge, but only in a limited area. ${ }^{45}$

The senses, of course are not enough as the only means of epistemology. Therefore, according to Motahhari, the Qur'an also mentions something called lub and hijr, the center of thought (ratio) as a means of gaining knowledge other than the senses. In surah An-Nahl: 78 above, the ratio is referred to as al-Afidah, which also means the heart, and / or a power of sorting (tajziyah) and compiling (tarkib), generalizing (ta'mim), letting go (tajrid), ${ }^{46}$ and syllogism (burhan). ${ }^{47}$ This power is called the strength of the ratio, in which it plays an important role for the birth process of science. He asserted that this ratio is not called an epistemology tool, because this ratio, as revealed above, is referred to as a source of epistemology, but the strength of this ratio is recognized as a means of gaining knowledge.

As revealed in this verse, the senses, logical arguments, and purification of the soul are expressed as one of the favors of Allah SWT, therefore, humans must give thanks by using the three according to their respective paths. Humans are grateful for the eyes of favor by observing and studying nature, grateful for the ears by listening to the goodness, and grateful for the pleasure of the ratio by way of thinking, pondering, sorting, arranging, generalizing, and releasing. ${ }^{48}$

In addition to senses and logical arguments, Motahhari also tried to prove naqliyah that purification of the soul is recognized by the Qur'an as a means of knowledge. For this purpose, Motahhari used the proposition, for example surah Asy-Shams: 7-9, "And the soul and its perfection (creation), then Allah inspired the soul (the way) of ungodliness and piety, Surely the one who fortifies the soul is purified." This

\footnotetext{
${ }^{45}$ Muthahhari, Mengenal Epistemologi: Sebuah Pembuktian Terhadap Rapuhnya Pemikiran Asing dan Kokohnya Pemikiran Islam, 58-60

${ }^{46}$ Ibid, 61

${ }^{47}$ Ibid, 87

${ }^{48} \mathrm{Ibid}, 64$
} 
Jurnal Hunafa: Studia Islamika, Volume 16, Number 2, p. 1- 150

E-ISSN: $2355-7710$

P-ISSN: $1411-125 \mathrm{X}$

purpose, according to him, clearly proves that purification is one of a means of gaining knowledge. ${ }^{49}$

The study of the scientific works of others, according to Motahhari, is also included as a fourth means to achieve science. The evidence used as a supporter is surah Al-Alaq: 1-5, "Read by the name of your Lord who created, He created man from a clot of blood, read, and your Lord is merciful, who teaches (human) with the delivery of kalam, He taught humans what he did not know."50

Despite the validity of the epistemological facilities above, all of these epistemological facilities have different study areas (objects). Humans must not confuse them with each other. ${ }^{51}$ For example, sense, as one of the means of epistemology, can only reach the physical realm. While the logic of the study area is the argumentation of non-material nature (rational), and purification of the soul only makes the heart as the object of study. ${ }^{52}$

\section{MENDHAHHARI'S THINKING AGENDA}

Thought is a product of history. Every thought reflects the situation and condition of its time, as well as Motahhari's thought. To understand the agenda of his thoughts, we must depart from the surrounding social settings.

Motahhari is a prolific writer who has produced many writings on various themes. This, according to Haidar Bagir, can give the impression that he is a generalist who has no clear agenda and perspective in his thought career. However, continued Bagir, such an impression is not appropriate, because basically Motahhari has an agenda that can be clearly found through his works. ${ }^{53}$

${ }^{49}$ Muthahhari, Manusia dan Alam Semesta: Konsepsi Islam Tentang Jagat Raya, 186

${ }^{50} \mathrm{Ibid}, 184$

${ }^{51}$ Muthahhari, Mengenal Epistemologi: Sebuah Pembuktian Terhadap Rapuhnya Pemikiran Asing dan Kokohnya Pemikiran Islam, 87

${ }^{52} \mathrm{Ibid}, 87$

${ }^{53}$ Haidar Bagir, “Membincang Metodologi Ayatullah Murtadha Muthahhari”, 1 
Jurnal Hunafa: Studia Islamika, Volume 16, Number 2, p. 1- 150

E-ISSN: 2355-7710

P-ISSN: $1411-125 \mathrm{X}$

The first agenda that can be seen is to instill the right way of thinking in Muslims. For Mutahhari, thinking and reflecting and intellectual understanding are the goals of a Muslim's life. Imagine, does not Islam see the purpose of life as Allah's makrifat (knowledge of Allah). Motahhari seems to hold that intellectual enlightenment is one of the highest happiness (See his treatise entitled Happiness). This is a kind of Aristotelian eudemonia, which is indeed the aim of every philosopher and thinker, Motahhari is no exception. To guarantee the validity of the results of a thought process, especially if it involves a concept of God that is so urgent for human happiness and at the same time so profound and complicated, then a methodology of correct thinking is absolute. ${ }^{54}$

The second agenda, explains the teachings of Islam in a way that suits the needs of modern humans for rational thoughts. Right thinking, of course not enough for Motahhari. But more than that he must be able to teach Muslims how to think correctly, rationally and philosophically. The teachings of Maxism and Materialism which strongly influenced Muslims, especially in Iran during his lifetime, were a serious threat. From this we can understand why he paid serious attention to the importance of Islamic epistemology. ${ }^{55}$

The third agenda, still related to the second agenda above, which is to criticize the perspective of materialism while at the same time explaining the foundations of philosophy and the Islamic world view which is considered to be a more accountable alternative. This rationale also underlies the fourth agenda, which forms a strong and coherent foundation for the development of Islamic systems in various fields of life, including political systems, economic systems, social systems, and so on. So it is not surprising if we find his works appearing in various topics. But in that diversity we can see clear methodological characteristics as explained earlier. The point is, he wants the formation of a world view of Islam, because according to him, ideology is always rooted in the

${ }^{54}$ Ibid., 3-4

${ }^{55} \mathrm{Ibid}$. 
Jurnal Hunafa: Studia Islamika, Volume 16, Number 2, p. 1- 150

E-ISSN: $2355-7710$

P-ISSN: $1411-125 \mathrm{X}$

world view. Monotheistic World .,view, Prophecy and Revelation, Conception of Society and History, Imamat, and Conception of the End Times. ${ }^{56}$

The Islamic world view that Mutahhari wants to establish is a monotheistic world view, as an alternative to the world view of materialism which has a great influence on Muslims. He divided the understanding of monotheism into two parts: theoretical monotheism and practical monotheism. Theoretical monotheism is monotheism that discusses the unity of matter, nature and deeds of God is specifically related to our beliefs, knowledge, perceptions and thoughts about God, while "practical monotheism" which is also called "monotheism of worship" is a relationship with the practical life of humans, it is a applied from "theoretical monotheism"

Theologians, according to Mutahhari, put more emphasis on "theoretical monotheism" and never reached the level of "practical monotheism" and sincerity. Because of this, it appears that besides they are theoretical monotheism, they are practically associating partners with Allah in deeds, servitude to things and people. ${ }^{58}$

\section{CONCLUSION}

Mutahhari is one of the modern Islamic philosophers who are very concerned about the need for an Islamic world view. He can marry rationalphilosophical thinking with the messages of the scriptures in response to the present

Mutahhari's rational-philosophical method of thinking is shown consistently in all his intellectual works spread over a variety of topics. This is at the same time as a learning for people to see the reality of life with an Islamic

${ }^{56}$ Ibid., 5

${ }^{57}$ Zainun Kamal, "Pemikiran Murtadha Muthahhari di Bidang Teologi” al-Hikmah: Jurnal Studi-Studi Islam, (1992), 102; Murtadha Muthahhari, Keadilan Ilahi, (Bandung: Mizan, 1995), 224

${ }^{58}$ Zainun Kamal, Ibid. 
Jurnal Hunafa: Studia Islamika, Volume 16, Number 2, p. 1- 150

E-ISSN: $2355-7710$

P-ISSN: $1411-125 \mathrm{X}$

world view, monotheistic world view. So that the concept of monotheism is not only a passive theological-theoretical concept, but also as a way of thinking and acting.

\section{REFERENCES}

Ahmad, Mumtaz, Masalah-Masalah Teori Politik Islam, Bandung, Cet. III; Pen. Mizan, 1996

Algar,Hamid, "Hidup dan Karya Murtadha Muthahhari" dalam Murtadha Muthahhari, Filsafat Hikmah, Terj. Tim Penerjemah Mizan, Bandung: Mizan, 2002

Bagir, Haidar, "Membincang Metodologi Ayatullah Murtadha Muthahhari" makalah disampaikan dalam Seminar Sehari Pemikiran Murtadha Muthahhari "Teologi Islam dan Persoalan Kontemporer" Ruang Seminar, Gd. Pascasarjana UGM Sabtu, 15 Mei 2004

Loren Bagus, Kamus Populer Filsafat, Jakarta: Gramedia, 1996

Beik, Abdullah, "Murtadha Muthahhari; Muslim dalam Aqidah, Syari'ah dan Akhlaq", dalam Majalah Al-Isyraq, No.4/Th.I, Jumadhil Akhir-Rajab, 1417 $\mathrm{H}$.

Dewan Redaksi Ensiklopedi Islam, Ensiklopedi Islam, Jilid 3, Jakarta, Pen. Ichtiar Baru Van Hoeve, 1994

Hernowo, "Tamasya Intelektual Seorang Ulama", dalam Al-Hikmah: Jurnal StudiStudi Islam,No. 1, Bandung, Yayasan Muthahhari, 1990.

Ja'far, Muhammad, "Pandangan Muthahhari Tentang Agama, Sejarah, Al- Quran dan Muhammad", dalam Jurnal Kajian Ilmu-Ilmu Islam Al-Huda, Vol. III. No.11. 2005

Kamal, Zainun, "Pemikiran Muthahhari di bidang Teologi"dalam Al-Hikmah: Jurnal Studi-Studi Islam,No. 4, Bandung, Yayasan Muthahhari, 1992

Kartanegara, Mulyadhi, Nalar Religius: Memahami Hakikat Tuhan, Alam, dan Manusia, Jakarta: Erlangga, 2007

Labib, Muhsin, Filosof Sebelum dan Sesudah Mulla Shadra, Jakarta: Lentera, 2005

_-_--, "Hawzah Ilmiyah Qom: Ladang Peternakan Filosof Muslim Benua Lain", dalam Jurnal Kajian Ilmu-ilmu Islam Al-Huda, Vol. III. No.9. 2003

Muthahhari, Murtadha, Perspektif Alqur'an tentang Manusia dan Agama, Pengantar Oleh Jalaluddin Rahmat, Cet. IV;Bandung: Mizan, 1990 
Jurnal Hunafa: Studia Islamika, Volume 16, Number 2, p. 1- 150

E-ISSN: $2355-7710$

P-ISSN: $1411-125 \mathrm{X}$

, Masyarakat dan Sejarah, Bandung: Mizan, 1995

, Keadilan Ilahi. Bandung: Mizan,1995

,Ceramah-Ceramah Seputar Persoalan Penting Agama dan Kehidupan, Buku Pertama, terjemahan Ahmad Subandi, Jakarta: Lentera, 1999

,Ceramah-Ceramah Seputar Persoalan Penting Agama dan Kehidupan, Buku Kedua, terjemahan Ahmad Subandi, Jakarta: Lentera, 2000

,Mengenal Epistemologi: Sebuah Pembuktian Terhadap Rapuhnya Pemikiran Asing dan Kokohnya Pemikiran Islam, terj. M.J. Bafaqih, Jakarta: Lentera, 2001

,Manusia dan Alam Semesta: Konsepsi Islam Tentang Jagat Raya, terj. Ilyas Hasan, Jakarta: Lentera, 2002

Nasr, Seyyed Hossein, "Pengantar", dalam Muhammad Husein Thabathaba'i, Hikmah Islam, Terj. Husein Anis Al-Habsy, Bandung: Mizan, 1993

Nasution, Harun, Filsafat Agama, Jakarta: Bulan Bintang, 1973

Rastan,Sastan, "Syahid Murtadha Muthahhari; Pembangkit Kebangunan Intelektual Islam”, dalam majalah Yaum Al-Quds, No. 9, Ramadhan 1403 H.

Runes, Bagobert D., Dictionary of Philosophy,Tottawa New Jersey: Adam's \& Co, 1971 